\title{
EFFECT OF PALM FIBERS ADDITION ON ABSORPTION CHARACTERISTICS AND MECHANICAL PROPERTIES OF CONCRETE
}

\author{
Hassan Ghanem ${ }^{1, \mathrm{a}}$, Meheddene Machaka ${ }^{1, \mathrm{~b}}$, Jamal Khatib ${ }^{1, \mathrm{c}}$, Adel Elkordi1, \\ Oussama Baalbaki ${ }^{1, \mathrm{e}}$
}

${ }^{1}$ Beirut Arab University, Department of civil and environmental engineering, Beirut, Lebanon. ${ }^{\mathrm{a}}$ Email: <h.ghanem@bau.edu.lb>; ${ }^{\mathrm{b}}$ Email: < m.mashaka@bau.edu.lb>; ${ }^{\mathrm{c} E m a i l: j . k h a t i b @ b a u . e d u . l b ;}{ }^{\mathrm{d}}$ Email: a.elkordi@bau.edu.lb; ${ }^{\mathrm{e}}$ Email: <obaalbaki@bau.edu.lb>.

\begin{abstract}
The effect of palm fibers on the absorption and mechanical properties of hardened concrete is presented in this paper. To achieve this aim, four concrete mixes were prepared with varying amount of fibers. The volume of fiber in the mix is $0 \%, 0.5 \%$, $1 \%$ and $1.5 \%$. The water to cement ratio for all mixes is kept constant. Five tests were performed for each concrete mixtures: ultrasonic pulse velocity, compressive strength, density, sorptivity and total water absorption. Concrete were cured for 3, 7, 28 and 90 days. Results indicated that acceptable concrete quality can be achieved with the addition of palm fibers. On the other side, the inclusion of palm fibers reduces the compressive strength up to $30 \%$ on average and the density by $4 \%$ as the percentage of fibers increases from $0 \%$ to $1.5 \%$. In addition, the capillary water absorption coefficient and total absorption increase with the increase of palm fibers but decreases significantly with curing durations.
\end{abstract}

Keywords: Palm fibers, Absorption characteristics, Mechanical properties, curing durations.

\section{INTRODUCTION}

The construction industry is considered a major sector in many countries around the world, including Lebanon. Unfortunately, this industry shares responsibility in depleting large amount of non-renewable resources and for $30 \%$ of carbon dioxide emissions (1). Therefore, many local agencies are urging the construction industry to use renewable resources to attain a more sustainable consumption pattern of construction materials. This is now apparent from the research conducted in the last few decades where waste and recycled products were used in concrete production (254) 
Concrete is widely considered the most used materials in construction. However, It has low tensile strength and low ductility. The concrete-steel reinforced bars combination is needed to overcome those disadvantages. However, steel which is derived from a nonrenewable source is an expensive material. It has high energy consumption and a tendency to corrode with time as concrete permeability increases during its life time. To compensate those shortcomings and for environment protection purposes, natural fibers have been proposed by materials engineers as a possible replacement for steel in construction works. A distinctive property of natural fibers concrete composite are improved bending and tensile strength, greater resistance to cracking and consequently, better strength and toughness (55). Researchers have tried in the past decade different types of natural fibers such as sisal, jute, rice husk, flax, bamboo, banana fiber, oil palm fiber and date palm fibers $(56,57)$. Although few previous studies provided promising results, there are still concerns regarding natural fibers high variation properties which could possibly lead to unpredictable concrete properties such as durability and strength, etc. (58-61). A major problem in using natural fibers is that the fibers present in an alkaline environment will decompose over time. Thus, concrete matrix loses its strength, leading to a sudden brittle failure. For this reason, chemical treatment of natural fibers before introducing it to the mixture is necessary $(62,63)$.

In this study, the focus is on the fan palm fibers (FPF) as it seems more suitable for exploitation. It was shown in a previous work that FPF in a $4 \%$ sodium hydroxide for 24 hours was the preferred treatment procedure as it yielded the highest tensile strength (59-63). In a subsequent study focusing on the effect of using FPF on the mechanical properties and durability of concrete, it was found that the compressive strength was not affected with the addition of low percentage of fibers. On the other hand, the resistance to plastic shrinkage cracking increased significantly with the addition of FPF and the optimum fiber percentage was found at 1.5\% (61-63). A more recent experimental study investigated the effect of FPF on concrete durability exposed to severe environments (sea water and magnesium sulfate). Results confirmed the beneficial effect of FPF as it reduces length concrete variation between $18 \%$ and $42 \%$ yielding volume stability of the composite $(60,61)$.

This paper is a continuation of a previous work on FPF with specific focus on its effect on the absorptions and mechanical properties of concrete. Results of this investigation are expected to pave the road for utilizing these natural materials in local construction to achieve a sustainable composite.

\section{EXPERIMENTAL STUDY}

\section{Materials}

The natural fibers investigated in this work are pulled out from the leaves of Fan Palm Trees widely available in main roads in urban and rural areas as shown in Figure 1. The leaves were then air dried for a week, split into fibers $1.0 \mathrm{~mm}$ width and then washed in water to remove any impurities. The FPF were then chemically treated for 24 hours in a $4 \%$ sodium hydroxide solution to improve the interface between the 
FPF and the concrete matrix as it plays a critical role in determining the absorption and mechanical properties of the composite. A weak interface ultimately leads to a low strength and stiffness but high resistance to fracture. The mechanical properties of FPF are presented in Table 1.

The cement used in this study is ordinary Portland Cement type I obtained from SIBLIN plant located in the mount-Lebanon. The cement complies with all requirements according to Libnor NL53. Sand used in the mixtures was from the Dibbieh area and has fineness modulus of 2.7. Coarse aggregate is a crushed limestone obtained from Mount-Lebanon. The particle distribution of sand and coarse aggregate met the requirement of ASTMC33 and C136. The physical properties of aggregates are shown in Table 2. Drinking-quality water was used in all concrete mixtures. Due to the nature of the investigation, a high workability was targeted. Thus, a High Range Water Reducer (SIKAMEN NN-Type F) was included in the mixtures.

\section{Mix Designs}

Four concrete mixtures were conducted in this study. Of the four concrete mix designs, three contain different percentage of FPF $(0.5 \%, 1 \%$ and $1.5 \%)$. The fourth mix does not contain FPF acting the role of a control sample. The absolute volume method was adopted in designing the mixtures. The water cement ratio for all mixtures was fixed at 0.6 and the ratio of cement to aggregates was equal to 4 . Air entrained is added to obtain a $2 \%$ air in the mixtures. For each parameter setting, two replicate specimens were tested. The total number of specimens tested is 300 . The key mixture design information is presented in Table 3.

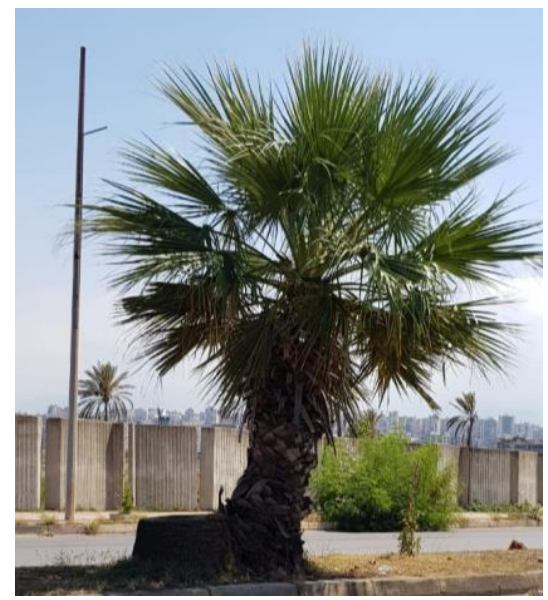

Figure. 1 Fan palm Fibers

Table 1. Mechanical properties of FPF

\begin{tabular}{|c|c|c|c|c|c|c|c|}
\hline Prop & $\begin{array}{c}\text { Thickness } \\
{[\mathrm{mm}]}\end{array}$ & $\begin{array}{l}\text { Width } \\
{[\mathrm{mm}]}\end{array}$ & $\begin{array}{c}\text { Bulk } \\
\text { Density } \\
{\left[\mathrm{Kg} / \mathrm{m}^{3}\right]}\end{array}$ & $\begin{array}{c}\text { Absorption } \\
{[\%]}\end{array}$ & $\begin{array}{c}\text { Mod. of } \\
\text { elasticity } \\
\text { [GPa] }\end{array}$ & $\begin{array}{c}\text { Tensile } \\
\text { strength } \\
{[\mathrm{MPa}]}\end{array}$ & $\begin{array}{c}\text { Elongatio } \\
{[\%]}\end{array}$ \\
\hline
\end{tabular}




\begin{tabular}{|c|c|c|c|c|c|c|c|}
\hline $\begin{array}{l}\text { Lower } \\
\text { limit }\end{array}$ & 0.25 & 0.60 & 500 & 100 & 4.5 & 70 & 1.5 \\
\hline $\begin{array}{l}\text { Upper } \\
\text { limit }\end{array}$ & 0.35 & 0.90 & 600 & 200 & 6.5 & 120 & 2.0 \\
\hline
\end{tabular}

Table 2. Coarse and fine aggregates properties

\begin{tabular}{|c|c|c|c|}
\hline Aggregate Type & Bulk Relative Density & Absorption \% & FM \\
\hline Fine: Natural sand & 2.51 & $1.56 \%$ & 2.7 \\
\hline Coarse: Crushed stone & 2.60 & $1.35 \%$ & \\
\hline
\end{tabular}

Table. 3 Mix proportions

\begin{tabular}{|c|c|c|c|c|c|c|}
\hline Mix \# & $\begin{array}{c}\text { FPF } \\
(\%)\end{array}$ & W/C ratio & $\begin{array}{c}\text { Water } \\
\left(\mathrm{kg} / \mathrm{m}^{3}\right)\end{array}$ & $\begin{array}{c}\text { Cement } \\
\left(\mathrm{Kg} / \mathrm{m}^{3}\right)\end{array}$ & $\begin{array}{c}\text { Coarse Agg } \\
\left(\mathrm{Kg} / \mathrm{m}^{3}\right)\end{array}$ & $\begin{array}{c}\text { Sand } \\
\left(\mathrm{Kg} / \mathrm{m}^{3}\right)\end{array}$ \\
\hline 1 & 0 & 0.6 & 210 & 350 & 1050 & 640 \\
\hline
\end{tabular}

\section{Sample Preparation}

The materials were weighed based on their proportions. They were then placed in a conventional concrete mixer. The sand, aggregates and $50 \%$ of water were first mixed for one minute. Then, the FPF were added slowly to the mixtures with $30 \%$ of water and mixed for 3 more minutes. This was done to prevent clumping of fibers. After adding all cement quantity, the remaining $20 \%$ of water was added. To check the workability of concrete, immediately after the mixing procedure is over, the slump test was conducted. The slump of all mixtures was found to be in the range of 12-15 $\mathrm{cm}$ indicating good workability. Following the flow test, the concrete was directly poured into the molds. For the compressive strength and the ultrasonic pulse velocity test, standard steel cylinders molds $15 \times 30 \mathrm{~cm}$ are used whereas $10 \times 20 \mathrm{~cm}$ steel molds were used for the density and total water absorption (TWA) test. For the capillary water absorption (CWA) test, standard cubes specimens with internal dimensions $100 \times 100 \times 100 \mathrm{~mm}$ are used. All concrete specimens were cured and tested at 3, 7, 28 and 90 days.

\section{Test Procedure}

The compressive strength of concrete was measured in accordance with ASTM C39 using a universal testing machine with a rate loading of $3 \mathrm{kN} / \mathrm{s}$ (64). The dry density of concrete specimens was determined according with ASTM C642 (65), on an electronic balance $610 \mathrm{P}$ with a precision of $\pm 0.1 \%$ under the following climatic conditions, $\mathrm{T}=20 \pm 2{ }^{\circ} \mathrm{C}$ and $\mathrm{RH}=65 \pm 2 \%$. The propagation of sound velocity across concrete samples was measured in accordance with ASTM C597 (66-67). The apparatus (UPV-Proceq) is composed of an electric pulse generator, a transmitter and a receiver. The transmitter and the receiver were placed on opposite side of the specimen. The sound velocity across concrete is calculated as follows:

$V=l / m(\mathrm{~m} / \mathrm{s})$ where $l$ is the distance separating the transmitter and the receiver $(\mathrm{m})$ and $t$ is the propagation time read by the apparatus (s). 
The TWA is a nondestructive test conducted on concrete samples to measure the amount of water absorbed after a specific period of time. Following 3, 7, 14 and 28 days of curing, the concrete specimens are placed in oven at $80 \mathrm{C}$ for $48 \mathrm{hrs}$ until a constant mass is reached. Afterwards, the cylinders are totally immersed in water for $24 \mathrm{hrs}$ and then removed, wiped with a towel to remove any water on the surface and the weight is again recorded. The TWA is obtained by determining the \% increase in the weight of the specimens between the above time intervals.

Water absorption tests were carried out to determine the sorptivity coefficient (well known as the CWA coefficient) of concrete specimens which were preconditioned in oven at $80 \mathrm{C}$ until a constant mass of the sample is reached. The four sides of the cubes were sealed with a non-absorbent coating to avoid evaporative effect and to maintain the uniaxial water flow during the test. The top and bottom sides were left unsealed and the sample weight is recorded. The specimen was then placed in container and water was poured into it up to $5 \mathrm{~mm}$ of the concrete cubes measured from the bottom of the specimens as shown in Figure 2. The water absorption at predetermined intervals $(3,5,10,20,30,60,120,140 \mathrm{~min}$ and 1, 2 and 3 days) was measured to an accuracy of $0.1 \mathrm{~g}$. From those measurement, the sorptivity coefficient $(S)$ can be calculated by the following expression:

$S=(Q / A) / \sqrt{t}$ Where: $Q$ is the volume of water absorbed $\left(\mathrm{cm}^{3}\right), A$ is the surface area in contact with water $\left(\mathrm{cm}^{2}\right)$ and $\mathrm{t}$ is the time (s). $S$ was obtained from the slope of the linear relationship between $Q / A$ and $\sqrt{t}$.

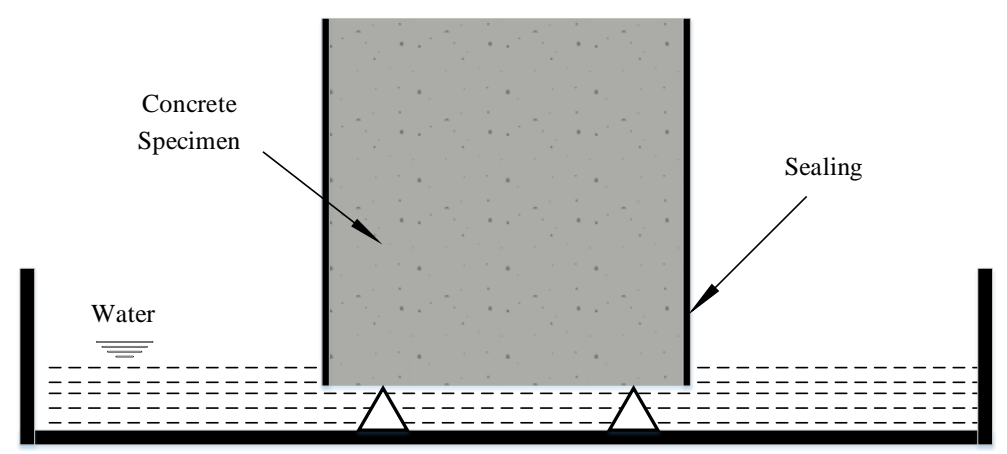

Figure 2 Sorptivity test

\section{RESULTS AND DISCUSSION}

The results of the compressive strength, density, UPV, TWA and CWA tests, data analysis and the correlation between the various tests will be presented in the following sections.

\section{Compressive Strength}

The compressive strength is regarded as one of the main properties of concrete. It depends on many factors such as mix proportions, water cement ratio, curing and the amount of fibers. The results of the compressive strength of $15 \times 30 \mathrm{~cm}$ cylinders presented in Figure 3a. This figure displays a set of relations between the concrete 
compressive strength and the curing duration for mixtures containing different amount of FPF. As shown, all plots display similar characteristics pattern. Compressive strength increases as curing durations increase and this is irrespective of the amount of FPF in the mixture. The results are very much expected.

Several other important observations can be deducted from the plots. The compressive strength of the control mixture displays the highest strength among all mixtures and the relationship between the percentages of FPF in concrete and the compressive strength is inversely proportional. In other words, as the $\%$ of FPF increases in the mixtures, the compressive strength of concrete cylinders goes down and this can be noticed for all curing durations. For example, for a curing period of 7 days, the compressive strength for the control mixture is $23.1 \mathrm{MPa}$ whereas it is 20.89 MPa for the mixture containing $0.5 \%$ FPF. Similarly, the strength continues to decrease to 16.1 and $14.9 \mathrm{MPa}$ for mixtures comprising $1 \%$ and $1.5 \& \mathrm{FPF}$ respectively. Therefore, one can deduct that the addition of FPF to concrete is damaging to the compressive strength. This can be due to the following phenomena: the FPF has a high water retention and this is considered beneficial to the hydration process. However, this will lead to shrinkage of FPF in the matrix, which debonds the fibers from the matrix. Therefore, the $\%$ voids increases with time at the fiber-matrix interface which explains the reduction in strength for all cylinders containing FPF with aging.

Although the above finding indicates that the addition of FPF to the mixture will not promote strength, it is important to determine precisely the $\%$ decrease in compressive strength for all concrete mixtures at all curing duration as this will allow concrete technologists determine the maximum permitted amount of FPF in concrete. Results of the analysis are shown in Figure $3 \mathrm{~b}$. At $0.5 \%$ FPF, the $\%$ decrease was not significant $(16 \%, 10 \%, 17 \%$ and $18 \%$ at $3,7,28$, and 90 days). On the other side, at $1.5 \% \mathrm{FPF}$, the drop increase to $35 \%, 32 \%$ and $28 \%$ at 7,28 and 90 days. Consequently, based on the above results, it can be concluded that increasing the $\%$ fiber volume fraction beyond $1 \%$ will lead to detrimental effect on concrete compressive strength.

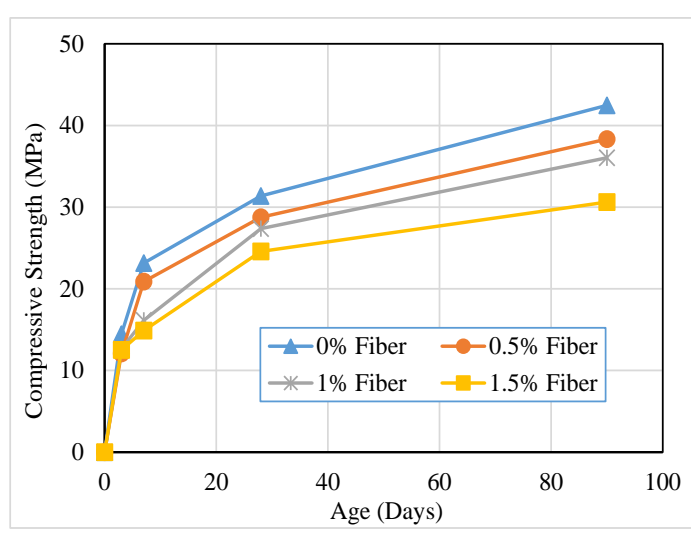

Figure 3a. Effect of FPF on comp. strength results

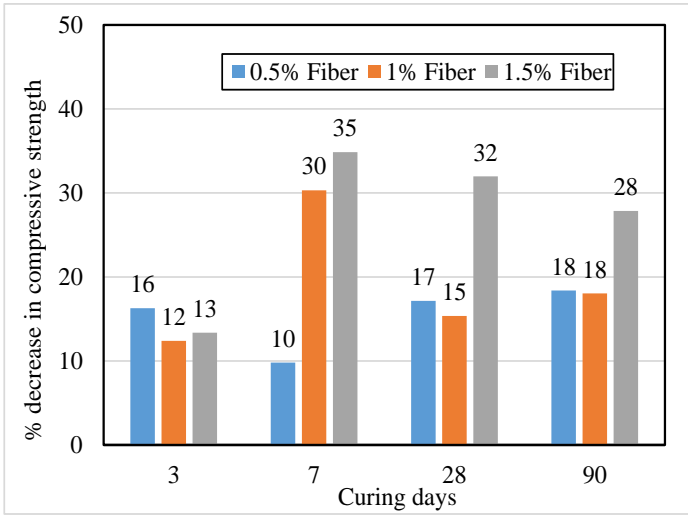

Figure $3 b . \%$ decrease of strength 


\section{Density}

Concrete density depends on the density of aggregate, amount of air entrapped and cement and maximum size of aggregate used. Density results are shown in Figure 4. The addition of FPF to the mixtures reduces slightly the density by 1 to $4 \%$ depending on the amount of fibers present. This is possibly due to the fact that the density of FPF is lower compared to concrete ingredients, which eventually reduces the overall concrete density. It can as well be seen that the highest decrease was found in the mixtures containing the highest amount of FPF (1.5\%) and this can be noticed at all curing durations. This maybe due to the high volume of FPF in the mixture that lead to higher quanity of entrapped air in the matrix.

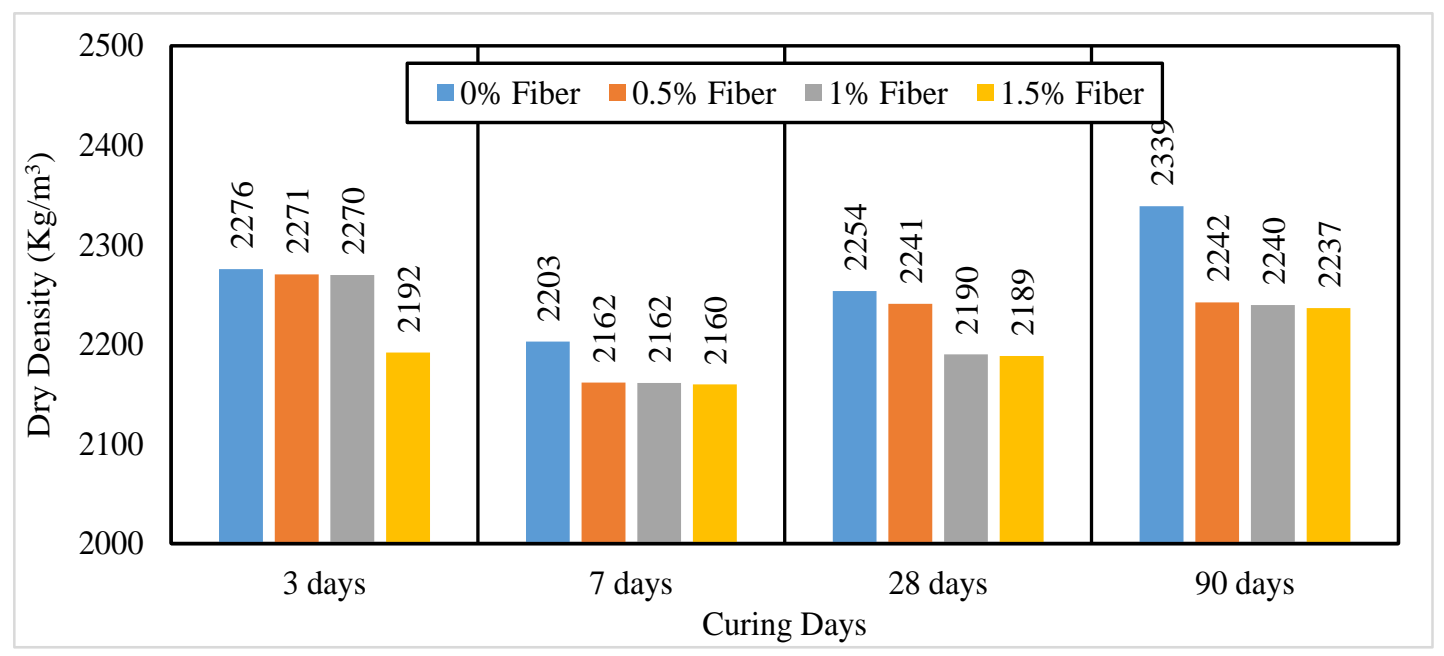

Figure 4. Effect of FPF and curing durations on concrete dry density

\section{Ultrasonic Pulse Velocity}

The ultrasonic pulse velocity (UPV) test is a nondestructive test to check the quality of concrete. Table 4 provides the classification of concrete based on the pulse velocity (67). A shown in the table, higher velocity indicates higher concrete quality in terms of density, uniformity, etc. whereas lower velocity points to low quality in terms of cracks, defects, presence of voids and other discontinuities.

Table 4. Classification of the quality of concrete on the basis of pulse velocity (67)

\begin{tabular}{|c|c|}
\hline Pulse Velocity & Quality of Concrete \\
\hline$>4.5 \mathrm{~km} / \mathrm{s}$ & Excellent \\
\hline $3.5-4.5 \mathrm{~km} / \mathrm{s}$ & Good \\
\hline $3.0-3.5 \mathrm{~km} / \mathrm{s}$ & Doubtful \\
\hline $2.0-3.0 \mathrm{~km} / \mathrm{s}$ & Poor \\
\hline$<2.0$ & Very poor \\
\hline
\end{tabular}


In this study, the UPV test was conducted on all concrete samples at all ages. Results are presented in Figure. 5. Several interesting observations can be made. First, all UPV readings for all samples are above $4 \mathrm{~km} / \mathrm{sec}$ indicating good concrete quality and the inclusions of FPF into the matrix did not affect negatively its quality. Second, the presence of FPF into the mixtures reduces slightly the UPV results by $1-3 \%$ on average. It is worth mentioning that UPV results are very consistent with the density results. Third, as curing duration increases, UPV values goes up and this is irrespective of the amount of FPF in the mixtures. For example, UPV value is 4.09 $(1.5 \% \mathrm{FPF})$ at 3 days whereas it is 4.4 at 90 days classifying effectively the concrete as excellent. This last point is very expected as the moisture level plays an important role during hydration leading to the development of hydration product contributing to the strength and uniformity of concrete.

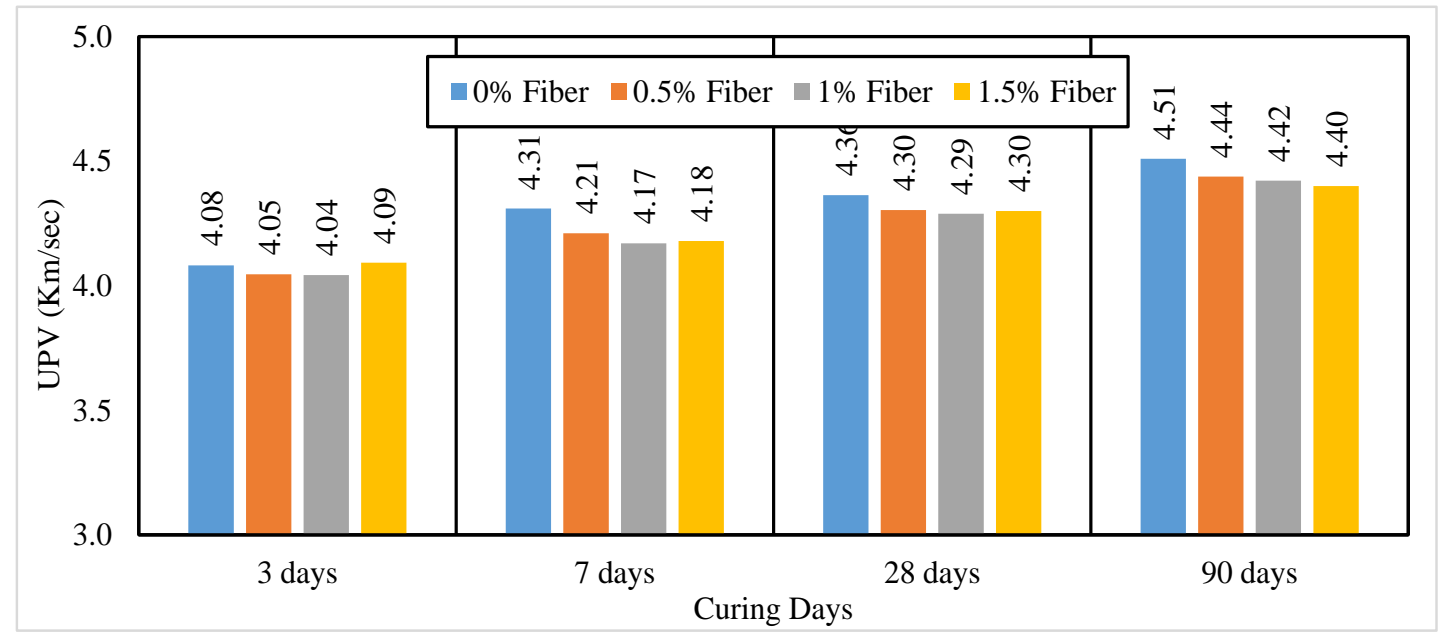

Figure 5. UPV test results

\section{Total Water Absorption (TWA)}

TWA can be considered a relevant parameter that can be related to the performance of concrete. The TWA depends on many factors: mixture proportions, curing duration, air content, presence of chemical admixtures and supplementary cementitious materials, etc.

Results are presented in Figure 6. Many remarks can be noticed. At 3 days, the TWA goes up as the \% FPF increases. For example, the TWA is 5.5\%, 5.6\%, $5.6 \%$ and $6.2 \%$ for samples containing $0 \%, 0.5 \%, 1 \%$ and $1.5 \%$ respectively. On the other side, the TWA values remain almost constant at 28 days for all mixtures (5.4\%). At 90 days, the results are perplexing. The TWA values increases from $3.8 \%$ to $5 \%$ and then decreases to 4.9 followed by a sudden drop to $2.1 \%$ for mixtures containing $0 \%$, $0.5 \%, 1 \%$ and $1.5 \%$ respectively. Although any drop in the TWA values in some mixtures is looked at positively as it increases concrete durability and its resistance to external agents, it is apparent that there is no clear trend in the TWA results and that 
the presence of FPF is not the main factor affecting concrete absorptions properties. On a separate note, it can be shown from the plots that the effect of curing on TWA are pretty significant. For example, for mixtures containing $1.5 \%$ FPF, the TWA is $6.2 \%, 5.9 \%, 5.4 \%$ and $2.1 \%$ at 3, 7, 28 and 90 days curing respectively. This is equivalent to $5 \%, 15 \%$ and $67 \%$ decrease. This can be easily explained as follows: as water absorption reflects the porosity of the matrix, the increase in curing leads to the capillary pores in concrete being filled with water resulting in a reduction of water absorption with time.

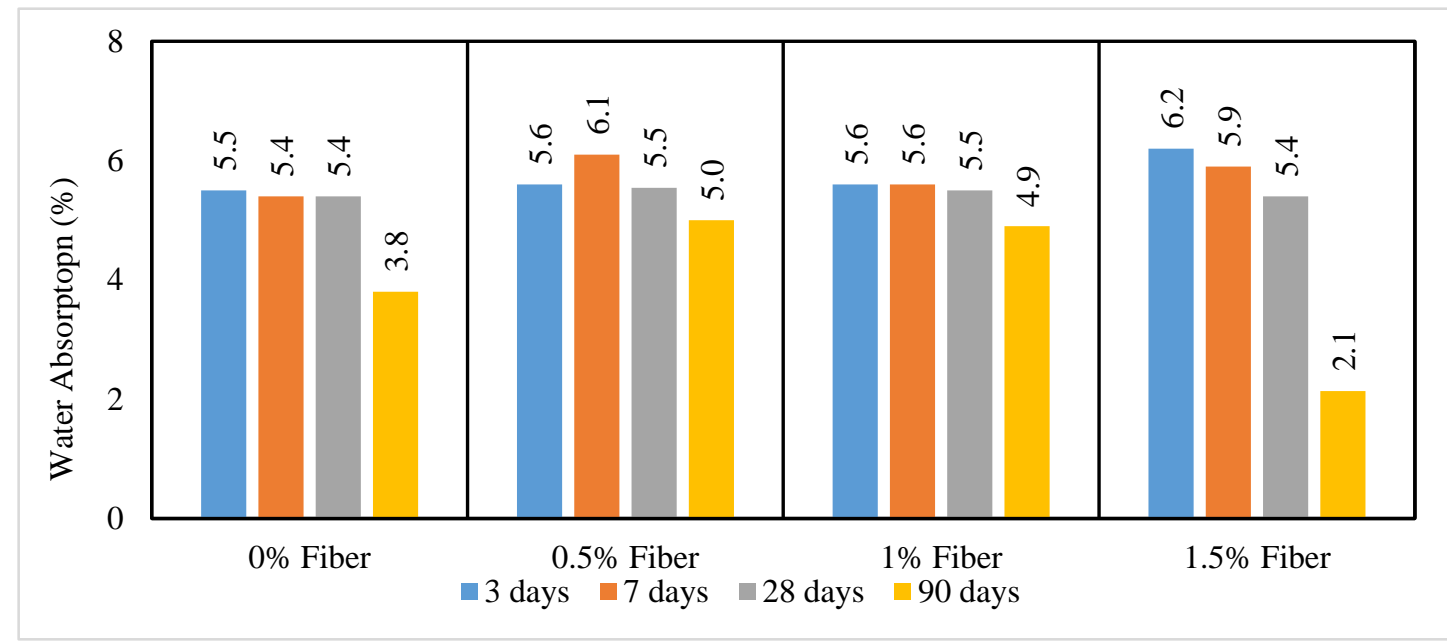

Figure 6. Effect of FPF on TWA

\section{Capillary Water Absorption (CWA)}

CWA is the movement of water into the concrete matrix through the small pores without an external applied hydraulic head. It is considered the primary transport mechanism and faster and more damaging than other mechanisms. A set of relations between the CWA coefficient (sorptivity) and curing durations for all mixtures are presented in Figure 7.

Several points can be mentioned. First, the relation between sorptivity and the $\%$ of FPF is proportional. In other words, as the \% of FPF increases, the sorptivity raises as well. For example, at 90 curing days the sorptivity values are $0.14,0.23,0.28$ and 0.31 for mixtures containing $0 \%, 0.5 \%, 1 \%$ and $1.5 \%$ FPF. This is possibly due to the following. In the first 2-3 weeks following casting, the water needed for hydration comes from two sources: 1) water added initially to the mixture, and 2) water relinquished unwillingly from the FPF. With time, the rate of hydration slows down. As FPF is hygroscopic in nature, it will try to absorb capillary water located in its vicinity. This will ultimately result in an increase of capillary forces into the matrix. As $\%$ of FPF goes up in to the mixtures, those capillary forces increase leading to a surge in sorptivity values. Second, the relation between curing duration and sorptivity is inversely proportional. The sorptivity drops significantly with curing periods. This reduction in sorptivity values ( 0.36 at 3 days versus 0.28 at 90 days for $1 \% \mathrm{FPF}$ ) indicates better concrete performance as any increase in curing durations results in a change in concrete microstructure. i.e. concrete becomes denser as it will be much 
more difficult for water to penetrate deeper into the concrete as capillary transport prevails only in the superficial layers that present open and connected pores.

Concrete absorption is related to its durability. The lower the absorption, the better the durability. Although achieving 0\% absorption is practically impossible, it is interesting to determine the \% increase in CWA as curing periods and \% FPF goes up. Results shown in Figure $7 \mathrm{~b}$ indicate that concrete containing $1.5 \%$ FPF at all curing ages yields the highest increase: $20 \%, 20 \%, 42 \%$ and $131 \%$ at 3, 7, 28 and 90 days respectively. Mixtures holding lower amount of fibers generates lower percentages. Thus, it can be deduced that raising the $\%$ fibers in the matrix beyond $1 \%$ may affect negatively concrete durability.

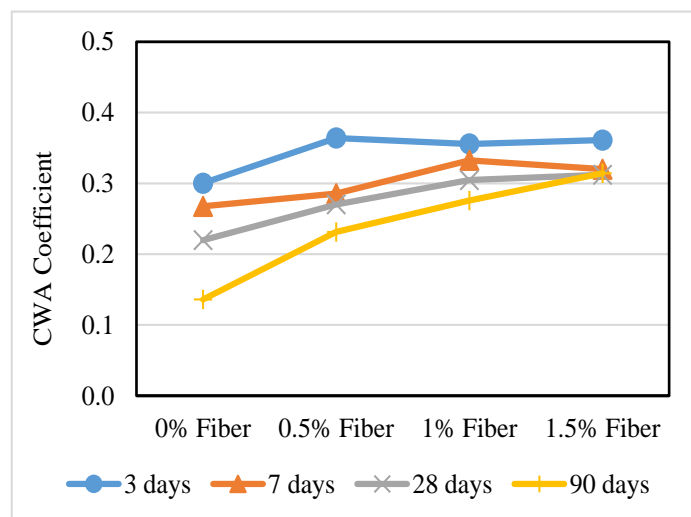

Figure 7. a) CWA coefficient results $\%$ fibers.

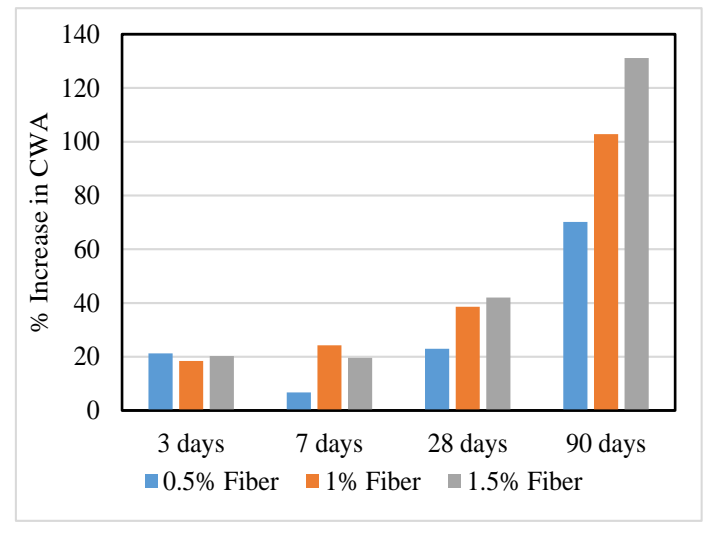

b) \% increase in CWA with age and

\section{Correlations}

As mentioned previously, the compressive strength test is a destructive test whereas the UPV, TWA and the CWA test is not. Therefore, researchers have shown interest in the past to explore the relationships between compressive strength, UPV, TWA and CWA. Because of the variability in the mixture design, those relationships do not have a general pattern and the strength of concrete mixtures can't not be determined accurately (67). However, in this study, we have explored the connections between the compressive strength, UPV and TWA. Figure 8a illustrates those relationships at all curing ages and a general best fit formula is developed. As shown, the compressive strength increases with UPV and draws near a linear relationship and the coefficient of determination $\mathrm{R}^{2}$ is $0.18,0.78,0.61$ and 0.85 at $3,7,10$ and 14 curing days respectively. Data analysis indicates a high correlation between UPV and compressive strength at all ages except at 3 days. This is possibly due to a measurement error of the UPV value at 3 days. The high correlation at other ages (7, 28 and 90 days) are consistent with our understanding that high UPV values indicate high quality concrete with minimum amount of voids which corresponds to higher compressive strength.

Another correlation was performed between the CWA coefficient and the compressive strength at 7, 14 and 28 days. Results are presented in Figure 8b. As 
shown, a general negative correlation exits between CWA and compressive strength. A decrease in CWA is accompanied by a corresponding increase in compressive strength. Clearly, the relationship was very strong (0.99 at 3 days, 0.91 at 7 days, 0.88 at 28 days and 0.91 at 28 days). At 28 days, the CWA was the lowest as more curing means less voids and thus higher compressive strength and more durable mortar. On the other side, CWA was highest at 3 days, as less curing period implies more voids and less hydration contributing to lower strength. It should be mentioned here all relationships shown in Figure 8 are case specific to this study as the UPV, compressive strength, TWA and CWA depend on many factors such as cementmortar paste content, water cement ratio, size of specimen and amount of FPF.

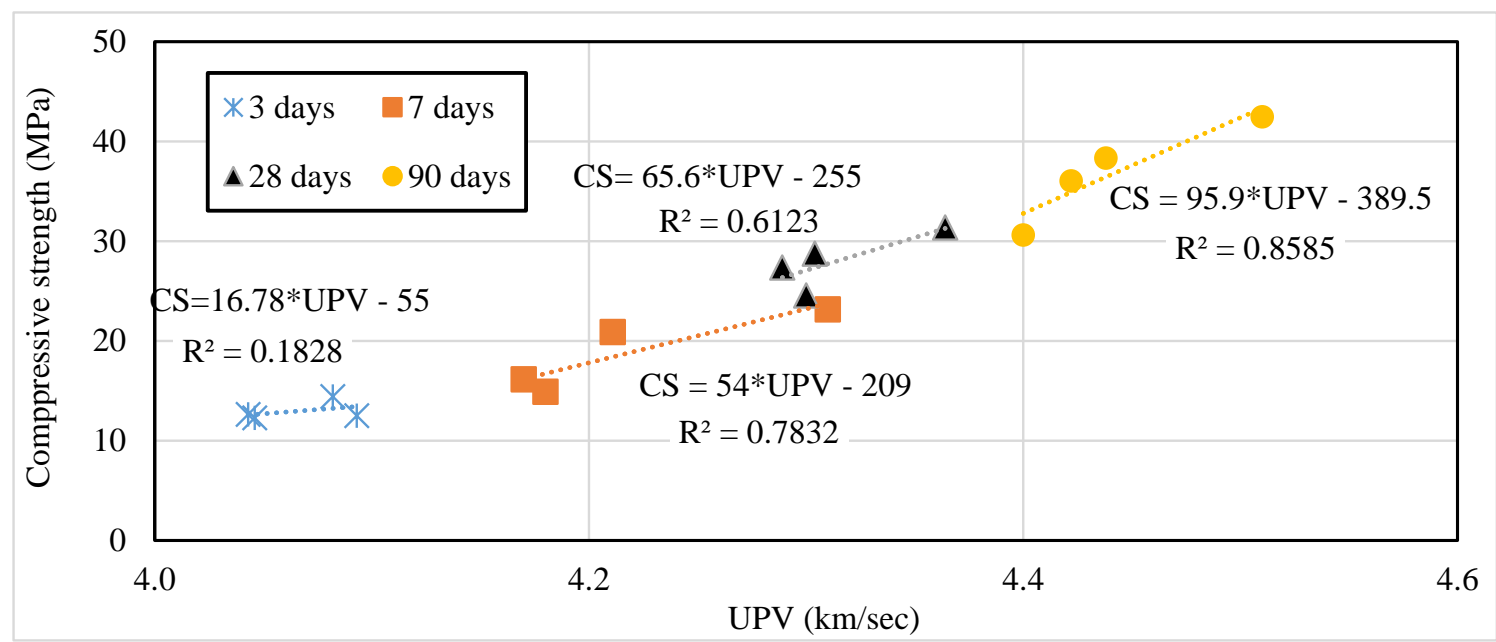

(a) Compressive strength vs UPV

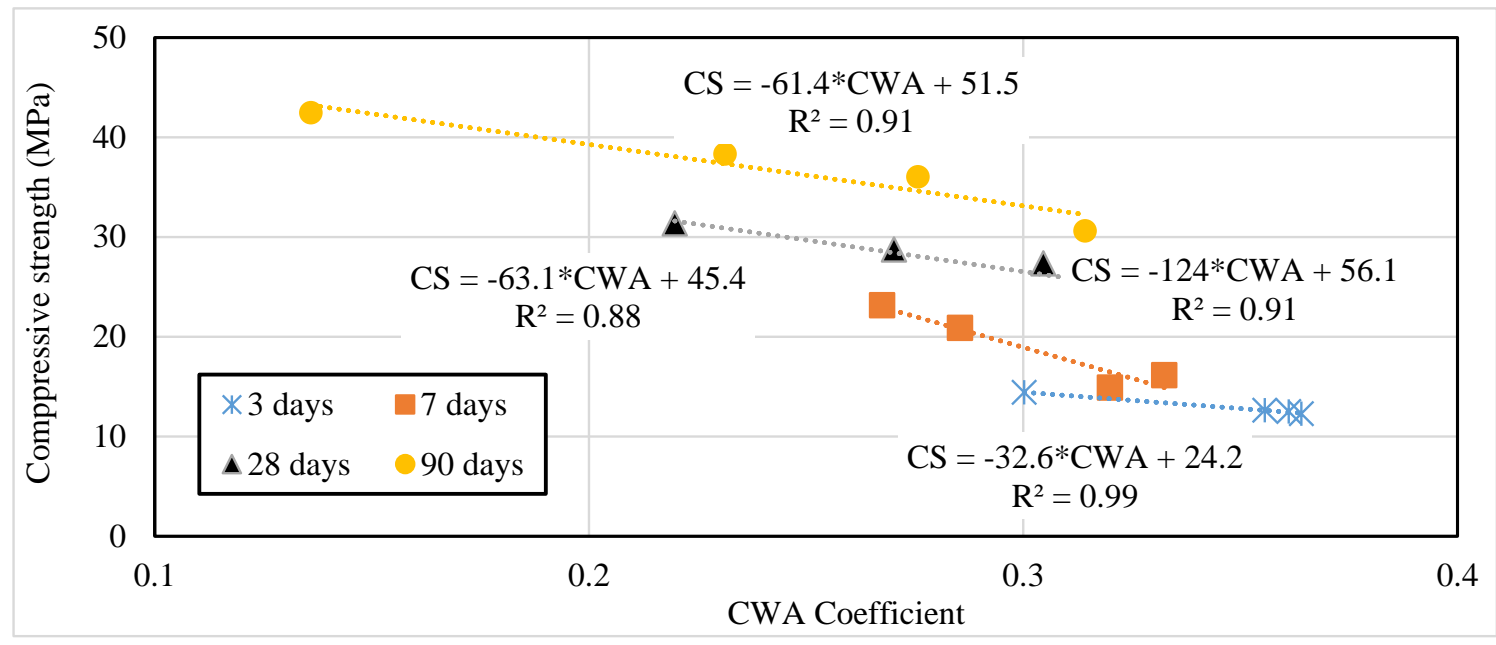

(b) Compressive strength vs CWA

Figure 8. Correlation between compressive strength and a) Ultrasonic pulse velocity (UPV) and b) capillary water absorption (CWA) 


\section{CONCLUSIONS}

For environment protection purposes, natural fibers like palm fibers are of special interest to material engineers. For this purpose, an experimental work was conducted to study their effects on mechanical and absorption properties of concrete. The conclusions derived from this study would be a step forward toward the development of design guidelines for the use FPF in concrete mixtures.

1. The presence of FPF decreases the compressive strength of concrete. It was found that at $1.5 \%$ FPF volume fraction, the drop in strength reaches $35 \%$ at 7 days.

2. There is slight reduction in density with the addition of fibers. This reduction ranges between 1 and $4 \%$.

3. At all curing periods, UPV results exceeded $4 \mathrm{~km} / \mathrm{sec}$ indicating good concrete quality, irrespective of the amount of FPF present. Thus, the concrete quality was not negatively impacted with the addition of palm fibers.

4. TWA results indicates that FPF was not the main factor affecting concrete absorptions properties. On the other side, the effect of curing age on absorption was pretty significant.

5. The relationship between CWA and \% FPF appears to be proportional and the highest $\%$ increase occurs at 90 days for mixtures containing $1.5 \%$ FPF. It was also found that curing duration is a major factor in determining CWA.

6. Data analysis of all tests displays a high correlation between the compressive strength and the UPV and between the strength and the CWA coefficient.

7. Based on this study, the $\%$ of FPF fibers in the matrix should not exceed $1 \%$ so that it doesn't impact negatively concrete durability.

\section{ACKNOWLEDGEMENT}

The authors gratefully acknowledge the assistance received from the technicians working at BAU Laboratories.

\section{REFERENCES}

1. Pacheco-Torgal, F., and Jalali, S., (2011) "Cementitious building materials reinforced with vegetable fibres: A review," Construction and Building Materials, 25(2), 575-581.

2. Bai, J. (2016) Durability of sustainable construction materials. In: Khatib, J.M. (ed.), Sustainability of Construction Materials. 2nd edition. Elsevier, pp. 399-416, In: Khatib, J.M. (ed.), Sustainability of Construction Materials. 2nd edition. Elsevier, pp. 33-54, ISBN 978-0-08-100995-6

3. Black, L. (2016), Low clinker cement as a sustainable construction material, In: Khatib, J.M. (ed.), Sustainability of Construction Materials. 2nd edition. Elsevier, pp. 417-460, ISBN 978-0-08-100995-6

4. Egenti, C. and Khatib, J.M. (2016). Sustainability of Compressed Earth. In: Khatib, J.M. (ed.), Sustainability of Construction Materials. 2nd edition. Elsevier, pp. 311-344, ISBN 978-0-08-100995-6 
5. Egenti, C., Khatib, J.M., and Oloke, D. (2014) Conceptualisation and Pilot Study of Shelled Compressed Earth Block for Sustainable Housing in Nigeria. International Journal of Sustainable Built Environment, 3 (1), 72-86, June, ISSN: 2212-6090, DOI: 10.1016/j.ijsbe.2014.05.002, http://www.journals.elsevier.com/international-journal-of-sustainable-builtenvironment/

6. El-Darwish, I.; Kurdi, A.; Mahmoud, H.; and Abou El-Kair, H. (1997) Mechanical Properties and Durability of Portland Cement Concrete Incorporating ground Steel Making Slag", Alexandria Engineering Journal, 36 (1), 1-14, January

7. El-Kurdi, A.A., Abdel-Hakam, A., and El-Gohary, M.M. (2014a) Study the effect of silica fume, polypropylene fiber, steel fiber, limestone powder and bentonite on the fire resistance of concrete. International Journal for Research and Analysis in Allied Sciences and Engineering, 1 (1), 13-29, April.

8. El-Kurdi, A.A., Abdel-Hakam, A., El-Gohary, M.M. (2014b) Impact of elevated temperature on properties of limestone concrete. International Journal of Innovative Technology and Exploring Engineering (IJITEE), 4 (4), 1-9, ISSN: 2278-3075

9. Hadjsadok, A., Kenai, S., Courard, L., Michel, F., and Khatib, J.M. (2012)

Durability of mortar and concretes containing slag with low hydraulic activity. Journal of Cement and Concrete Composites, 34 (5), 671-677, May 2012, ISSN 0958-9465. doi:10.1016/j.cemconcomp.2012.02.011

10. Hassan, M., Gardiner, P.H.E., Khatib, J.M., and Mangat, P.S. (2012) Stabilisation of Lead Contaminated Soil Using Portland Cement. International Workshop on Earthquake and Sustainable Materials, Sakarya University, Faculty of Technology, Civil Engineering Department, Turkey, 19 January 2012, pp 157167, ISBN: 978-975-7988-92-2. http://www.iwesm.sau.edu.tr/?s=s9

11. Herki, B.A. and Khatib, J.M. (2013) Lightweight concrete incorporating waste expanded polystyrene. Advanced Materials Research Journal, 787, 131-137, Trans Tech Publications, Switzerland, ISBN print: 978-3-03785-802-8, doi:10.4028/www.scientific.net/AMR.787.131

12. Herki, B.A. and Khatib, J.M. (2016) Valorisation of waste expanded polystyrene in concrete using a novel recycling technique. European Journal of Environmental and Civil Engineering, Taylor \& Francis pub, http://dx.doi.org/10.1080/19648189.2016.1170729

13. Khatib, J.M. (2005) Properties of concrete containing fine recycled aggregates. Cement and Concrete Research Journal, 35 (4), 763-769, April 2005. ISSN: 0008-8846 doi: 10.1016/j.cemconres.2004.06.017

14. Khatib, J.M. (2008) Metakaolin concrete at a low water to binder ratio. Construction and Building Materials Journal, 22 (8), 1691-1700, August 2008. ISSN 0950-0618 doi: 10.1016/j.conbuildmat.2007.06.003

15. Khatib, J.M. (2009) Low curing Temperature of Metakaolin Concrete. American Society of Civil Engineers (ASCE) - Materials in Civil Engineering Journal, 21 (8), 362-367, August, ISSN 0899-1561/2009/8-362-367 DOI: 10.1061/(ASCE)0899-1561(2009)21:8(362)

16. Khatib, J.M. (2014) Effect of initial curing on absorption and pore size distribution of paste and concrete containing slag. Korean Society of Civil 
Engineers (KSCE) Journal, 18 (1), 264-272, January. pISSN 1226-7988, eISSN 1976-3808 DOI 10.1007/s12205-014-0449-7

17. Khatib, J.M. and Ellis, D.J. (2001) Mechanical properties of concrete containing foundry sand. Fifth CANMET/ACI International Conference on Recent Advances in Concrete Technology, SP 200 (Ed. V M Malhotra), 29 July-1 August, Singapore, 2001, pp. 733-748, American Concrete Institute. ISBN 0-87031-0291. http://www.normas.com/ACI/pages/SP-200.html

18. Khatib, J.M. and Hibbert, J.J. (2005) Selected engineering properties of concrete incorporating slag and metakaolin. Construction and Building Materials Journal, 19 (6), 460-472, July 2005. ISSN 0950-0618 doi: 10.1016/j.conbuildmat.2004.07.017

19. Khatib, J.M. and Mangat, P.S. (1995) Absorption characteristics of concrete as a function of location relative to the casting position. Cement and Concrete Research Journal, 25 (5), 999-1010, July 1995. ISSN: 0008-8846

20. Khatib, J.M. and Mangat, P.S. (2003) Porosity of cement paste cured at $45^{\circ} \mathrm{C}$ as a function of location relative to casting position. Journal of Cement and Concrete Composites, 25 (1), 97-108.

21. Khatib, J.M. and Wild, S. (1998) Sulphate resistance of metakaolin mortar. Cement and Concrete Research Journal, 28 (1), 83-92. ISSN: 0008-8846

22. Khatib, J.M., Halliday, C., Negim, E.S.M., and Khatib, S. (2014b) Activation of fly ash paste with lime in the presence of small amount of metakaolin. Proceeding of International Forum on "Engineering Education and Science in the XXI Century: Challenges and Perspectives" - Devoted to the 80th Anniversary of Satpaev Kazntu, Vol. 1, 22-24 October 2014, Kazakh National University under the auspices of the Ministry of Education and Science, Almaty City Akimat, Kazakhstan , pp504-506, ISBN 978-601-228-666-3

23. Khatib, J.M., Herki, A.B., and Kenai, S. (2013c) Capillarity of concrete containing foundry sand. Journal of Construction and Building Materials, 47, 867-871, October, Elsevier http://dx.doi.org/10.1016/j.conbuildmat.2013.05.013

24. Khatib, J.M., Jefimiuk, A., and Khatib, S. (2015b) Flexural behaviour of reinforced concrete beams containing expanded glass as lightweight aggregates. Slovak Journal of Civil Engineering, 23 (4), 1-7, De Gruyter Publishing. doi: 10.1515/sjce-2015-007, http://www.svf.stuba.sk/generate_page.php?page_id=2075ISSN: 1210-3896

25. Khatib, J.M., Kayali, O., and Siddique, R. (2009) Strength and Dimensional Stability of Cement-Fly Ash-Metakaolin Mortar. American Society of Civil Engineers (ASCE) - Materials in Civil Engineering Journal, 21 (9), 523-528, September, ISSN 0899-1561/2009/9-523-528, DOI: 10.1061/(ASCE)08991561(2009)21:9(523), CODEN: JMCEE7

26. Khatib, J.M., Mangat, P.S., and Wright, L. (2008) Sulphate resistance of blended binders containing FGD waste. Construction Materials Journal Proceedings of the Institution of Civil Engineers (ICE), Vol. 161, Issue CM3, August 2008, pp. 119-128. ISNN 1747-650X doi: 10.1680/coma.2008.161.3.119

27. Khatib, J.M., Mangat, P.S., and Wright, L. (2013b) Early Age Porosity and Pore Size Distribution of Cement paste with Flue Gas Desulphurisation (FGD) Waste. Journal of Civil Engineering and Management, 19 (5), 622-627, Taylor \& 
Francis, ISSN 1392-3730 print/ISSN 1822-3605 online, doi: 10.3846/13923730.2013.793609

28. Khatib, J.M., Mangat, P.S., and Wright, L. (2014a) Pore Size Distribution of Cement pastes Containing Fly Ash-Gypsum Blends Cured for 7 Days. Korean Society of Civil Engineering (KSCE) Journal, 18 (4), 1091-1096. doi: 10.1007/s12205-014-0136-8 Online ISSN: 1976-3808; Print ISSN: 1226-7988

29. Khatib, J.M., Negim, E.M., Sohl, H.S., and Chileshe, N. (2012b) Glass powder utilisation in concrete production. European Journal of Applied Sciences, 4 (4), 173-176, ISSN 2079-2077. doi; 10.5829/idosi.ejas.2012.4.4.1102

30. Khatib, J.M., Onaidhe, E., Sonebi, M., and Abdelgader, H. (2015a) Lime activation of fly ash in mortar in the presence of metakaolin. Proceedings of the 1st International Conference on Bio-based Building Materials (ICBBM 2015), Eds. Amziane and Sonebi, 21-24 June 2015, Claremont-Ferrand, France. RILEM publication, pp 107-110, ISBN PRO 99: 978-2-35158-154-4 https://sites.google.com/site/icbbm2015/home

31. Khatib, J.M., Shariff, S., and Negim, E.S.M. (2012a) Effect of incorporating foamed glass on the flexural behaviour of reinforced concrete beams. World Applied Sciences Journal, 19 (1), 47-51, ISSN 1818-4952,DOI: 10.5829/idosi.wasj.2012.19.01.2763

32. Khatib, J.M., Wright, L., and Mangat, P.S. (2013a)"Effect of fly ash-gypsum blend on porosity and pore size distribution of cement pastes. Journal of Advances in Applied Ceramics, Structural, Functional and Bioceramics, 112 (4), 197-201, online, ISSN 17436753, DOI: 10.1179/1743676112Y.0000000032

33. Khatib, J.M., Wright, L., and Mangat, P.S. (2016a) Mechanical and Physical Properties of Concrete Containing FGD Waste. Magazine of Concrete Research, Article number: MACR-D-15-00092. doi: 10.1680/macr.15.00092 (In Press).

34. Kinuthia, J.M. (2016). Sustainability of waste paper in construction. In: Khatib, J.M. ed. Sustainability of Construction Materials. 2nd edition. Elsevier, pp. 569-598, ISBN 978-0-08-100995-6

35. Kurdi, A., Awad, A., Kassim, M., and El-Zaafraney, M. (1996) Properties and usage of cement kiln dust in concrete. Alexandria Engineering Journal, 35 (5), 209-222.

36. Mangat, P.S. and El-Khatib, J.M. (1992) Influence of initial curing on sulphate resistance of blended cement concrete. Cement and Concrete Research Journal, 22, (6), 1089-1100, November 1992. ISSN: 0008-8846

37. Mangat, P.S. and Khatib, J.M. (1995) Influence of fly ash, silica fume and slag on sulphate resistance of concrete. American Concrete Institute-Materials Journal, 92 (5), 542-552.

38. Mangat, P.S. and Lambert, P. (2016) Sustainability of alkali-activated cementitious materials and geoplymers. In: Khatib, J.M. (ed.), Sustainability of Construction Materials. 2nd edition. Elsevier, pp. 461-478, ISBN 978-0-08100995-6

39. Mangat, P.S., Khatib, J.M., and Wright, L. (2006) Optimum Utilisation of Flue Gas Desulphurisation (FGD) Waste in Blended Binder for Concrete. Construction Materials Journal - Proceedings of the Institution of Civil Engineers, 1 (2), pp 60-68, August 2006. ISNN 1747-650X 
40. Menadi, B., Kenai, S., and Khatib, J.M. (2014) Fracture behaviour of concrete containing limestone fines. Proceedings of the ICE; Construction Materials Journal ,167 (3), 162-170, June 2014, Paper 1200041 DOI: 10.1680/coma.12.00041.

41. Menadi, B., Kenai, S., Khatib, J.M., and Ait-Mokhtar, A. (2009) Strength and durability of concrete incorporating crushed limestone sand. Construction and Building Materials Journal, 23 (2), 625-633, February 2009. ISSN 0950-0618, doi:10.1016/j.conbuildmat.2008.02.005

42. Morales-Hernandez, B., Khatib, J.M., and Gardiner, P. (2005) Use of Municipal Solid Waste Incineration Bottom Ash (MSWI-BA) in Cement Mortar. Proceedings of the 1st Global Slag Conference - From Problem to Opportunity, Dusseldorf, Germany, 14-15 November 2005, pp. 210-218. http://www.propubs.com/gsc/gs05reviewed.html

43. Okeyinka, O.M., Oloke, D.A., and Khatib, J.M. (2015) A review of recycle use of post-consumer waste paper in construction. Proceedings of the $1^{s t}$ International Conference on Bio-based Building Materials (ICBBM 2015), Eds. Amziane and Sonebi, 21-24 June 2015, Claremont-Ferrand, France. RILEM publication, pp. 711-717, ISBN PRO 99: 978-2-35158-154-4 https://sites.google.com/site/icbbm2015/home

44. Okeyinka, O.M., Oloke, D.A., and Khatib, J.M. (2017) "Strength and stiffness properties of the optimum mix composition of cement-less wastepaper-based lightweight block (CWLB)", WSEAS Transactions on Environment and Development, 13, pp 335-345. E-ISSN: 2224-3496.

45. Owens, P.L., Boarder, R., and Khatib, J.M. (2016). Sustainability of lightweight aggregates manufactured from waste clay for reducing the carbon footprint of concrete. In: Khatib, J.M. (ed.), Sustainability of Construction Materials. 2nd edition. Elsevier, pp. 209-246, ISBN 978-0-08-100995-6

46. Savastano, H., Jr., Santos, S.F., Fiorelli, J., and Agopyan, V. (2016) Sustainable use of vegetable fibres and particles in civil construction, In: Khatib, J.M. (ed.), Sustainability of Construction Materials. 2nd edition. Elsevier, pp. 479-522, ISBN 978-0-08-100995-6

47. Sonebi, M., Ammar, P., and Diederich, P. (2016) Sustainability of cement, concrete and cement replacement materials in construction. In: Khatib, J.M. (ed.), Sustainability of Construction Materials. 2nd edition. Elsevier, pp 417-460, ISBN 978-0-08-100995-6

48. Topçu, I.B. and Uygunoglu, T. (2016). Sustainability of waste rubber in construction. In: Khatib, J.M. (ed.), Sustainability of Construction Materials. 2nd edition. Elsevier, pp. 599-626, ISBN 978-0-08-100995-6

49. Widyatmoko, I. (2016). Sustainability of bituminous materilas in construction. In: Khatib, J.M. (ed.), Sustainability of Construction Materials. 2nd edition. Elsevier, pp. 345-372, ISBN 978-0-08-100995-6

50. Wild, S., Khatib, J.M., and Jones, A. (1996) Relative strength, pozzolanic activity and cement hydration in superplasticised metakaolin concrete. Cement and Concrete Research Journal, 16 (10), 1537-1544. ISSN: 0008-8846 
51. Wild, S., Khatib, J.M., and O'Farrell, M. (1997) Sulphate resistance of mortar containing ground brick clay calcined at different temperatures. Cement and Concrete Research Journal, 27 (5), 697-709. ISSN: 0008-8846

52. Wright, L. and Khatib, J.M. (2016) Sustainability of desulphurised waste materials in construction. In: Khatib, J.M. (ed.), Sustainability of Construction Materials, 2nd edition. Elsevier, pp. 685-720, ISBN 978-0-08-100995-6

53. Zhansaya, N., Negim, E.S.M., Rauash, A.M., Khatib, J.M., Mun, G.A., and Williams, C. (2014) Effect of $\mathrm{pH}$ on the physico-mechanical properties and miscibility of MC/PAA blends. Carbohydrate Polymers Journal, 101, 415-422, Elsevier, http://dx.doi.org/10.1016/j.carbpol.2013.09.047

54. Ghanem H., Obeid Y., Trad A., Dandachy M. (2019) The Impact of Steel Fibers on the Properties of Self Compacting Concrete. In: Rodrigues H., Elnashai A. (eds) Advances and Challenges in Structural Engineering. GeoMEast 2018. Sustainable Civil Infrastructures. Springer, Cham pp 138-150.

55. Toledo, Filho R.D., Scrivener K., England G.L. and Ghavani K. (2000), Durability of Alkali- Sensitive Sisal and Coconut Fibres in Cement Mortar Composites. The International Journal on Cement and Concrete Composites, 22, 127-143.

56. Dawood E.T., and Ramli, M. (2012) "Durability of high strength flowing concrete with hybrid fibers," Construction and Building Materials, 35, 521-530.

57. Erdoğan, U. H., Y. Seki, G. Aydoğdu, B. Kutlu, and A. Akşit. (2016). "Effect of different surface treatments on the properties of Jute." Journal of Natural Fibers, 13(2):158-71.

58. Machaka, M., Basha H., Abou Chakra H, ElKordi A. (2014) "Effect of alkali treatment on the mechanical properties of fan palm natural fibers for use in fiber reinforced concrete." European Scientific Journal, 10(12) 186-195.

59. Machaka, M. M., Basha, H. S., \& ElKordi, A. M. (2014), "The Effect of Using Fan Palm Natural Fibers on the Mechanical Properties and Durability of Concrete." International Journal of Materials Science, 2(2), 76-80.

60. Machaka, M. and ElKordi, A., (2017) "The effect of using fan palm natural fibers on the impact resistance of concrete." 1st International Turkish World Engineering and Science Congress in Antalya, Turkey.

61. Machaka, M., and ElKordi A. (2017) "Experimental study of the effect of adding fan palm fibers on concrete durability exposed to severe environments" 2nd international conference on bio-based building materials \& 1st conference on ecological valorisation of granular and fibrous materials, Clermont-Ferrand, France.

62. Cai, M., H. Takagi, A. N. Nakagaito, M. Katoh, T. Ueki, G. I. N. Waterhouse, and Y. Li. (2015). "Influence of alkaline treatment on internal microstructure and tensile properties of abaca fiber." Industrial Crops and Products, 65:27-35.

63. Jamasri, H., and Kusmono, (2018). "Effect of chemical treatments on tensile properties and interfacial shear strength of unsaturated polyester/fan palm fibers." Journal of Natural Fibers, 15(5), 1-14.

64. ASTM C39/C39M (2018). "Standard Test Method for Compressive Strength of Cylindrical Concrete Specimens" ASTM International, West 


\section{Conshohocken, PA.}

65. ASTM C642 (2013) "Standard Test Method for Density, Absorption, and Voids in Hardened Concrete" ASTM International, West Conshohocken, PA.

66. ASTM C597 (2016) "Standard Test Method for Pulse Velocity through Concrete" ASTM International, West Conshohocken, PA.

67. International Atomic Energy Agency [IAEA]. (2002) Guidebook on nondestructive testing of concrete structures, Vienna, Austria. 